\title{
AORTOFEMORAL THROMBOENDARTERECTOMY
}

\author{
Eduardo Toledo de Aguiar, Alex Lederman, Cid José Sitrângulo Júnior and \\ Pedro Puech-Leão
}

RHCFAP/3087

AGUIAR ET et al. - Aortofemoral thromboendarterectomy. Rev. Hosp. Clín. Fac. Med. S. Paulo 57(4):147-160, 2002.

PURPOSE: To study whether endarterectomy is feasible in all patients with aortofemoral atherosclerotic obstruction, considering early and late results.

METHODS: A clinical, prospective, and descriptive study carried out in a university hospital. Inclusion criteria were atherosclerotic aortofemoral obstructive disease, clinical status compatible with major surgery, and absence of prior restorative procedure. Exclusion criteria were aneurysm, inflammatory arterial disease, and prior restorative procedure found during surgery. Eighty patients entered the protocol, but 9 were excluded (11.2\%). Seventy-one patients, mean age of 57.3 years, underwent endarterectomy. Operative indications were intermittent claudication and critical ischemia. A ring-stripper endarterectomy technique was employed in all patients. Results were related to age, gender, symptoms, presence of diabetes mellitus, extension of endarterectomy, and extent of obstructive disease. Chi square or Fisher exact tests were used when appropriate, and the Wilkoxon (Gehan) test was used to compare survival curves.

RESULTS: Sixty-eight $(100 \%)$ endarterectomies were patent at discharge. The mortality rate was $4.2 \%$. The amputation rate $(4.3 \%)$ was higher in diabetic patients and when there was associated femoropopliteal obstruction. The 5-year survival rate was $83.3 \%$, and late deaths were mostly cardiovascular. Diabetes mellitus, age above 65 years, and associated femoropopliteal obstruction lowered the survival rate. The 5-year patency rate was $87.0 \%$. Critical ischemia and less extensive endarterectomies were associated with a lower patency rate. There were no anastomotic aneurysms or deep infections.

CONCLUSIONS: Aortofemoral thromboendarterectomy is feasible in $90 \%$ of patients, early mortality rate is low, diabetic patients and those with associated femoropopliteal obstructive disease have a higher mortality rate, amputation rate is low, late deaths are mostly cardiovascular, and late patency rate is high, and even higher in the intermittent claudication group.

DESCRIPTORS: Aorta. Iliac artery. Endarterectomy. Atherosclerosis. Arterial reconstructive surgery.

\section{INTRODUCTION}

The first thromboendarterectomy was performed by Dos Santos in 1947, and after a few years, it was accepted as a treatment for aortoiliac atherosclerotic obstructions ${ }^{1-3}$. Technical difficulties induced most surgeons to substitute prosthetic aortoiliac bypass, an easier procedure, for endarterectomies.

During the 1950s, arterial prosthesis development caused a great advance in vascular surgery ${ }^{4}$. These arterial substitutes made aneurysm and arterial occlusion surgical treatment much easier and were employed indiscriminately to correct all chronic obstructions, regardless of the artery involved. Earlier results showed that these synthetic arterial grafts were not suitable for small caliber arteries, so for these vessels the saphenous vein became the ideal substitute. Dacron grafts became the ideal substitute for

From the Vascular Surgery Service, Hospital das Clínicas, Faculty of Medicine University of São Paulo. larger arteries and are widely used to treat the Leriche syndrome.

Unfortunately, patients with an arterial prosthesis are always at risk of complications developing after the graft implant. Anastomotic aneurysms and graft infections may occur at any time, and their surgical treatment is followed by high mortality in cases of graft infection ${ }^{5-9}$. Even with all the improvements in technology and surgical procedures, these complications are not preventable.

Some surgeons still use endarterec- 
tomy techniques to treat arterial occlusive disease. When reviewing the literature regarding the early and late complications of this technique, one finds instances of occlusion of the treated segment, but instances of infection and anastomotic aneurysms are not found.

In our service, thromboendarterectomy is rarely used, and the treatment of choice for aortoiliac occlusive disease is the aortofemoral Dacron bypass ${ }^{10,11}$. During the past few decades, frequently occurring graft infections that jeopardize the prosthesis and the patient's limb and life induced us to use an autogenous substitute and thus return to the use of thromboendarterectomy.

The objective of this study is to analyze whether thromboendarterectomy is feasible in all aortoiliac-femoral occlusions and whether early and late results are comparable to results from other techniques.

\section{METHODS}

This is a clinical prospective and descriptive study. Inclusion criteria were aortoiliac-femoral obstructions due to atherosclerosis with or without femoropopliteal occlusions, patient's clinical status allowing major vascular surgery, and absence of previous arterial aortoiliac-femoral and femoropopliteal reconstruction. Exclusion criteria were aneurysm diagnosed during surgery, arterial inflammatory disease diagnosed during surgery, or previous arterial surgery not mentioned prior to the operation and that was diagnosed during surgery.

Patients were randomly selected to participate in the protocol from the surgical ward of the university hospital. Patients who were admitted under the author's care and met inclusion criteria were then included. All patients had a preoperative angiography to study the infrarenal abdominal aorta, iliac arteries, and arteries of the lower limbs to the feet.

Ring-stripper endarterectomy under general anesthesia was performed on all patients. The aorta and iliac and femoral bifurcations were dissected. Dissec- tion of the aorta's left side, aortic bifurcation, and left common iliac artery was avoided. A clamp was located at the femoral bifurcation, and a transverse incision was made 1 centimeter above the clamp. The endarterectomy ring was introduced until the iliac bifurcation was reached. At this point, another arteriotomy of the common iliac artery was made 1 centimeter above the bifurcation, and the core was taken out. The internal iliac artery was then exposed, and any plaque that needed to be removed was taken out with the help of a Moynihan clamp. The ring was then introduced through the common iliac artery until it reached the aortic bifurcation. The same procedure was done on the other side. Aortic endarterectomy was completed with infrarenal crossclamping, longitudinal aortotomy, and "open endarterectomy". The common iliac core was removed through aortotomy. Closure of the aorta, iliac, and femoral arteriotomies was done sequentially, with clamp removal after each suture (Fig. 1).

The following parameters were
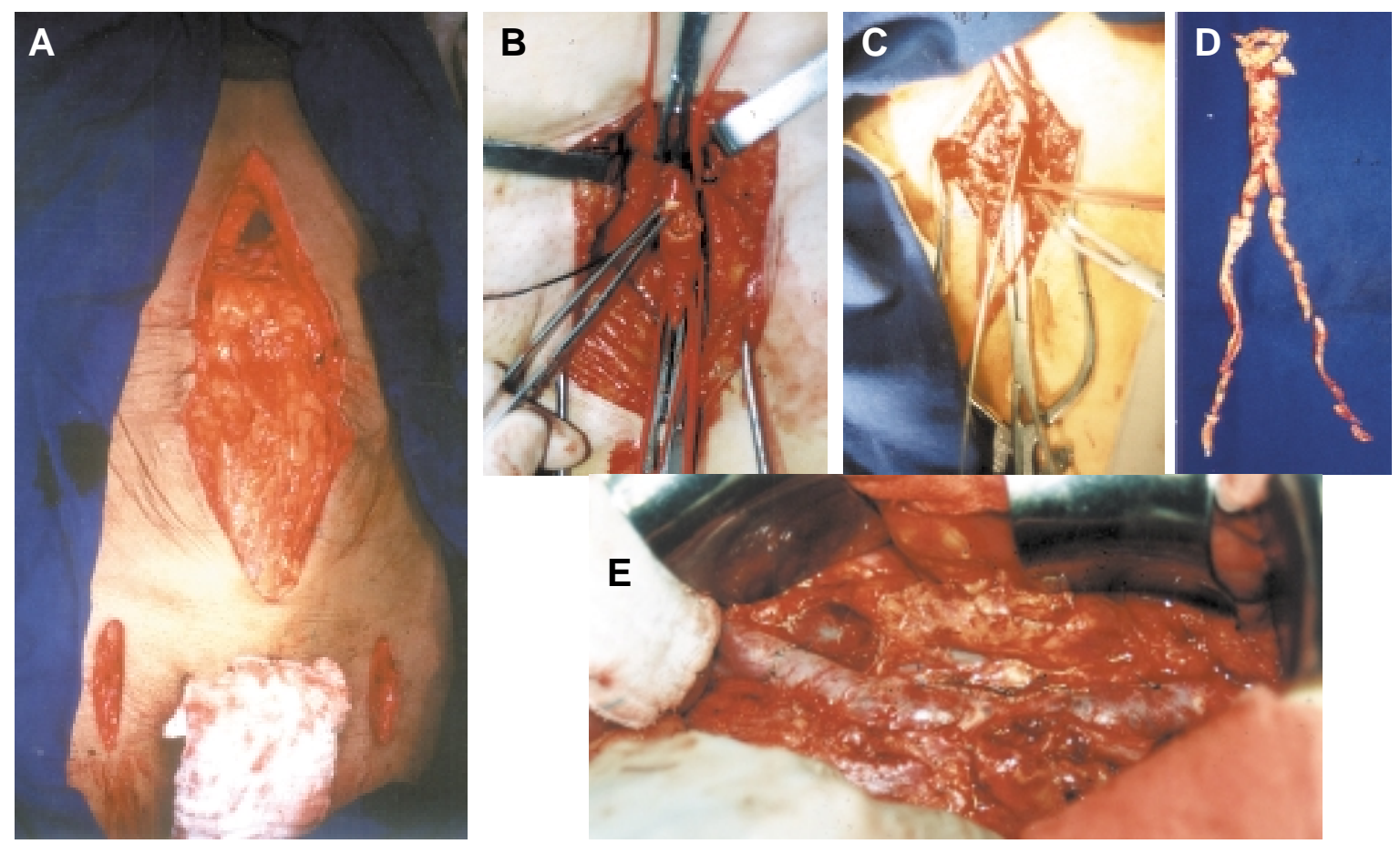

Figure 1 - Aortofemoral thromboendarterectomy steps. A - Incisions. B - Beginning of endarterectomy at common femoral artery. C - Ring stripper through common femoral artery. D - Atheroma plaques and thrombus. E - Longitudinal aortotomy and tranverse right iliac arteriotomy closed. 
analyzed: early and late mortality, early and late amputation rates, early reoperations (during first 30-day period), survival rate, late obstruction rate (verified by femoral pulse loss and duplex-scan), suture line aneurysms (physical examination and duplexscan), deep surgical infection (verified by the patient's clinical status and specific cultures for agent isolation).

All patients were followed with duplex-scan at 3 months after surgery and at least once a year after that.

The outcomes were then related to age, gender, symptoms, presence of diabetes mellitus, thromboendarterectomy extension, and occlusive disease extension into the aortoiliac-femoral territory, associated or not with femoropopliteal obstructive disease.

Chi-square and Fisher's Exact test were applied with a significance of $5 \%$. Survival curves were built for late death and late arterial occlusion. The Wilcoxon (Gehan) test was applied with a significance level of $5 \%$.

All statistical analyses were made using the SPSS for Windows program.

\section{PATIENTS}

Eighty patients were initially included. Nine $(11.2 \%)$ had to be excluded due to intraoperative findings -7 with abdominal aortic aneurysm, 1 with an aneurysm at the origin of the external iliac artery, and 1 with a pre-

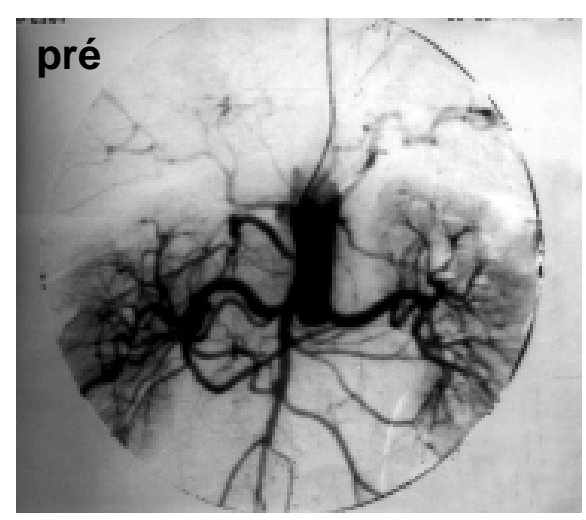

viously stented left common iliac artery (the stent did not show up on aortography because of subtraction technique).

Seventy-one patients were included. The mean age was $57.3 \pm 9.9$ years; $54(76.1 \%)$ were male and 17 (23.9\%) female. Twelve (16.9\%) were diabetic patients, 34 (47.9\%) were hypertensive patients, 70 (98.6\%) were smokers, 29 (40.8\%) had critical limb ischemia (rest pain with or without ischemic lesions), 42 (59.2\%) had intermittent claudication, 19 (26.8\%) had coronary artery disease, $12(16.9 \%)$ had carotid stenosis, and 32 (45.1\%) had femoropopliteal-associated occlusions.

The endarterectomy extension was aorto-bifemoral (3 with associated femoropopliteal restoration, 1 of which bilateral) in $52(73.2 \%)$ patients, aortoiliac on one side and aortofemoral on the other in $3(4.2 \%)$, and iliacfemoral (two bilateral and one with associated femoropopliteal bypass) in 9 (12.6\%).

Aorto-bifemoral and aortoiliac on one side and aortofemoral on the other were classified in one group (aortofemoral), and aortoiliac and iliacfemoral endarterectomies in another.

\section{RESULTS}

At hospital discharge, 68 (100\%) patients had patent restorations (3 early deaths excluded). The preoperative and postoperative angiograms of a patient with juxtarenal aortic occlusion in which the disease extended throughout the iliac arteries reaching the common femoral arteries are shown in figure 2. Thirteen (18.3\%) patients had immediate occlusion. One patient died of metabolic disorders, and the other 12 had a successful redo operation.

Reoperations were due to superficial femoral artery flaps (5), deep femoral artery occlusion caused by flaps (2), thrombosis due to hypotension (2), incomplete external iliac artery endarterectomy (2), and incomplete common iliac artery endarterectomy (1).

Three $(4.5 \%)$ patients had to undergo fasciotomy and developed neurological sequelae that disappeared within 6 months. One diabetic patient, after reoperation, developed a wound infection, calf abscess, and sepsis. Despite all complications, there was no compromise of arterial restoration.

There was no statistically significant association of reoperation rates with age group, gender, presence of diabetes, symptom type, endarterectomy extension, and presence of associated femoropopliteal occlusion.

Three amputations had to be done (amputation rate of 4.2\%): 2 at femoral level and 1 transmetatarsal (caused by atheroembolism on the contralateral limb after iliac-femoral endarterectomy). Acute small artery occlusion occurred during ring endarterectomy of the left common iliac artery to the aorta. The
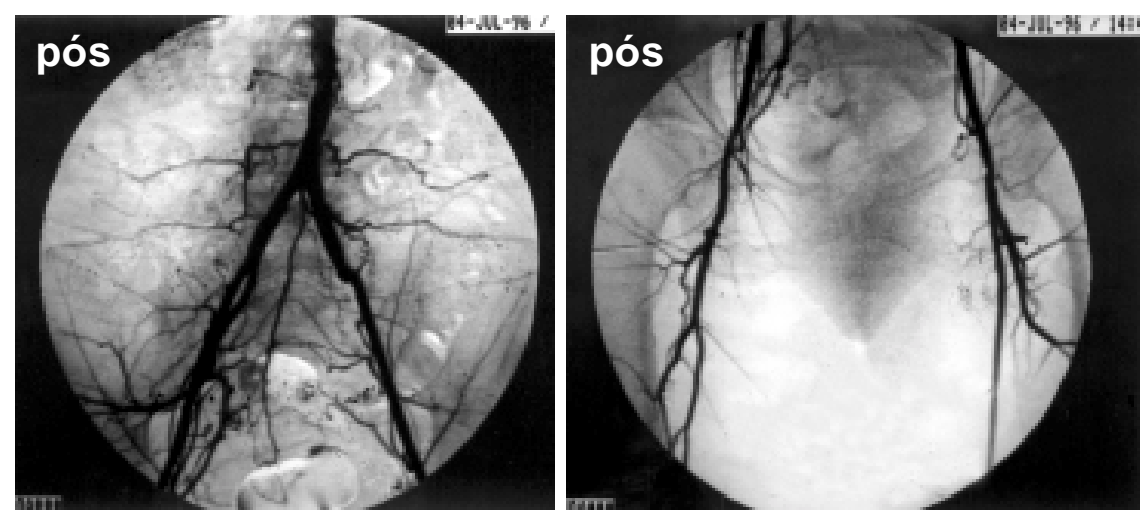

Figure 2 - Preoperative and postoperative angiography (aortofemoral thromboendarterectomy). 
other 2 amputations were due to extensive gangrene after aortoiliac-femoral thromboendarterectomy. Even with a successful arterial restoration, the ischemic lesion continued to develop in one patient. The other patient developed gaseous gangrene after surgery. Neither of these patients was diabetic.

There was no statistically significant association of amputation rates with age group, gender, presence of diabetes, or endarterectomy extension. A statistically significant association of amputation with type of symptom was found; amputations occurred only after operations done for critical ischemia.

Three patients died in the immediate postoperative period. All were male, 2 were older than 65 years of age, and 2 were diabetics. The mortality rate was $4.2 \%$. The causes of death were mesenteric thrombosis in a diabetic patient and mio-nephrotic-metabolic syndrome in 2 patients (one had an immediate postoperative thromboendarterectomy occlusion, and the other was a diabetic with a bilateral femoropopliteal obstruction with a clamping time greater than 2 hours due to technical difficulties). Two of these patients had surgery due to intermittent claudication, and the third one was due to critical ischemia. All 3 patients had aortoiliacfemoral thromboendarterectomy. There was no statistically significant association of mortality rates with age, gender, thromboendarterectomy extension, or patient's symptoms (Table 3). However, patients with diabetes and with associated femoropopliteal occlusions had a higher immediate death rate.

The life table shows a 5-year patency of $87.0 \% \pm 5.6 \%$ (Fig. 3); late reoperations were not included. Eight occlusions occurred after endarterectomy (through an inguinal incision only): 4 aortoiliac-femoral, 3 aortoiliac, 1 ileo-femoral. Five patients underwent reoperations successfully. Two years after primary surgery, the first patient de- veloped occlusion of both common femoral arteries to the origin of the deep femoral artery where endarterectomy was finished. Intimal hyperplasia was observed at that point. Correction by profundaplasty and thrombectomy was

successful. The second case had an external iliac artery endarterectomy $11 / 2$ years after primary aortoiliac endarterectomy. The third patient had an aortic aneurysm occlusion after a bilateral ileofemoral endarterectomy done

Table 1 - Immediate reoperation rate by variables studied.

\begin{tabular}{|c|c|c|c|c|}
\hline Variable & $\begin{array}{l}\text { Immediate } \\
\text { yes }\end{array}$ & $\begin{array}{l}\text { reoperation } \\
\text { no }\end{array}$ & Total & $\begin{array}{l}\text { Qui square or } \\
\text { Fisher exact } \\
\text { test }\end{array}$ \\
\hline \multicolumn{5}{|l|}{ Age } \\
\hline$<65$ years & 11 & 45 & 56 & \\
\hline$>65$ years & 2 & 13 & 15 & 0.15 \\
\hline \multicolumn{5}{|l|}{ Gender } \\
\hline Male & 8 & 46 & 54 & \\
\hline Female & 5 & 12 & 17 & 0.44 \\
\hline \multicolumn{5}{|l|}{ Symptoms } \\
\hline Intermittent claudication & 8 & 34 & 42 & \\
\hline Critical ischemia & 5 & 24 & 29 & 0.84 \\
\hline \multicolumn{5}{|l|}{ Diabetes mellitus } \\
\hline Yes & 1 & 11 & 12 & \\
\hline No & 12 & 47 & 59 & 0.30 \\
\hline \multicolumn{5}{|l|}{ Endarterectomy } \\
\hline $\begin{array}{l}\text { Aorto-bi-femoral } \\
\text { thromboendarterectomy }\end{array}$ & 11 & 41 & 52 & \\
\hline $\begin{array}{l}\text { Aortoiliac or ileo-femoral } \\
\text { thromboendarterectomy } \\
\text { Fem-pop }\end{array}$ & 2 & 17 & 19 & 0.25 \\
\hline Yes & 7 & 25 & 32 & \\
\hline No & 6 & 33 & 39 & 0.48 \\
\hline
\end{tabular}

Fem-pop: Femoropopliteal obstruction associated with aortoiliac-femoral obstruction.

Table 2 - Immediate post-operative amputation rate by variables studied.

\begin{tabular}{|c|c|c|c|c|}
\hline Variable & $\begin{array}{l}\text { Amputation } \\
\text { yes }\end{array}$ & no & Total & $\begin{array}{l}\text { Fisher exact } \\
\text { test }\end{array}$ \\
\hline \multicolumn{5}{|l|}{ Age } \\
\hline$<65$ years & 2 & 54 & 56 & \\
\hline$>65$ years & 1 & 14 & 15 & 0.51 \\
\hline \multicolumn{5}{|l|}{ Gender } \\
\hline Male & 2 & 52 & 54 & \\
\hline Female & 1 & 16 & 17 & 0.56 \\
\hline \multicolumn{5}{|l|}{ Symptoms } \\
\hline Intermittent claudication & 0 & 42 & 42 & \\
\hline Critical ischemia & 3 & 26 & 29 & 0.06 \\
\hline \multicolumn{5}{|l|}{ Diabetes mellitus } \\
\hline Yes & 0 & 12 & 12 & \\
\hline No & 3 & 56 & 59 & 0.56 \\
\hline \multicolumn{5}{|l|}{ Endarterectomy } \\
\hline $\begin{array}{l}\text { Aorto-bi-femoral } \\
\text { thromboendarterectomy }\end{array}$ & 2 & 50 & 52 & \\
\hline $\begin{array}{l}\text { Aortoiliac or ileo-femoral } \\
\text { thromboendarterectomy }\end{array}$ & 1 & 18 & 19 & 0.61 \\
\hline \multicolumn{5}{|l|}{ Fem-pop } \\
\hline Yes & 2 & 30 & 32 & \\
\hline No & 1 & 38 & 39 & 0.42 \\
\hline
\end{tabular}

Fem-pop: Femoropopliteal obstruction associated with aortoiliac-femoral obstruction. 
Table 3 - Immediate mortality by variables studied.

\begin{tabular}{|c|c|c|c|c|}
\hline Variable & $\begin{array}{l}\text { Death } \\
\text { yes }\end{array}$ & no & Total & $\begin{array}{l}\text { Fisher exact } \\
\text { test }\end{array}$ \\
\hline \multicolumn{5}{|l|}{ Age } \\
\hline$<65$ years & 1 & 55 & 56 & \\
\hline$>65$ years & 2 & 13 & 15 & 0.11 \\
\hline \multicolumn{5}{|l|}{ Gender } \\
\hline Male & 3 & 51 & 17 & \\
\hline Female & 0 & 17 & 17 & 0.43 \\
\hline \multicolumn{5}{|l|}{ Symptoms } \\
\hline Intermitten Claudication & 2 & 40 & 42 & \\
\hline Critical Ischemia & 1 & 28 & 29 & 0.63 \\
\hline \multicolumn{5}{|l|}{ Diabetes mellitus } \\
\hline Yes & 2 & 10 & 12 & \\
\hline No & 1 & 58 & 59 & 0.07 \\
\hline \multicolumn{5}{|l|}{ Endarterectomy } \\
\hline $\begin{array}{l}\text { Aorto-bi-femoral } \\
\text { thromboendarterectomy }\end{array}$ & 3 & 49 & 52 & \\
\hline $\begin{array}{l}\text { Aortoiliac or ileo femoral } \\
\text { thromboendarterectomy }\end{array}$ & 0 & 19 & 19 & 0.38 \\
\hline \multicolumn{5}{|l|}{ Fem-pop } \\
\hline Yes & 3 & 29 & 32 & \\
\hline No & 0 & 39 & 39 & 0.08 \\
\hline
\end{tabular}

Fem-pop: Femoropopliteal obstruction associated with aortoiliac-femoral obstruction.

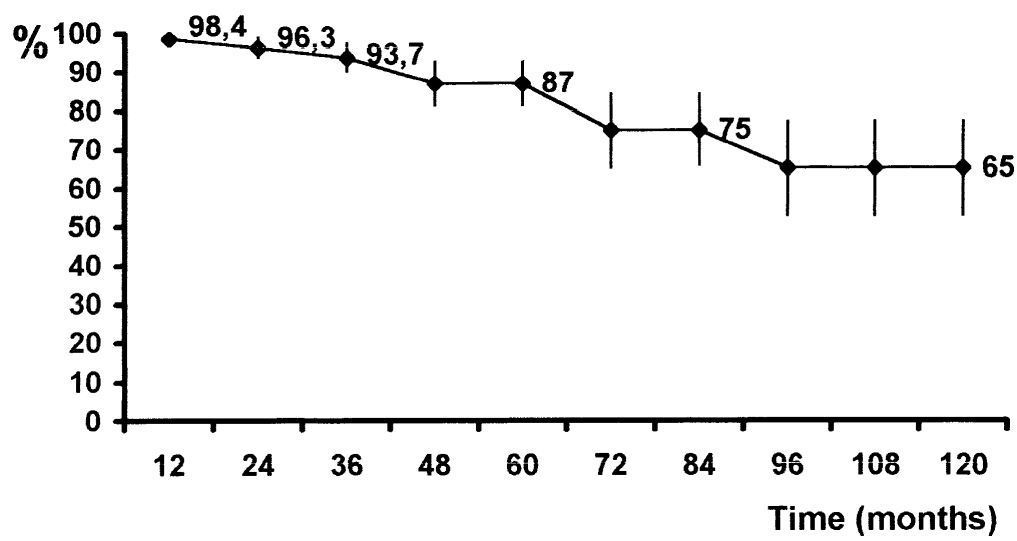

Number of operations included in the peiod:

$\begin{array}{lrrrrrrrrrrrrr}71 & 53 & 41 & 32 & 22 & 15 & 12 & 8 & & 6 & & 2 & \\ \text { Number of occlusions in the period: } \\ 1\end{array}$

Figure 3 - Patency of thromboendarterectomy.

through inguinal incisions. Diagnosis was done during reoperation 11 months after first surgery, and an aortofemoral "Dacron" bypass was performed. The fourth patient developed a left common iliac artery occlusion 5 years after primary surgery. During preoperative arteriography, a right common iliac artery stenosis was diagnosed. Ring endarterectomy was successful in treating the left-side occlusion. A balloon angio- plasty of the right-side stenosis was complicated by arterial rupture, and a Dacron tube was interposed. The fifth patient also developed a left-side common iliac artery stenosis that was successfully treated with balloon angioplasty that occluded at the $40^{\text {th }}$ postoperative day. A new thromboendarterectomy of this segment was successful. A sixth patient refused to undergo redo surgery 9 years after an aortoiliac-femo- ral endarterectomy. Two other patients are still under evaluation for possible reoperations (one with previous aortoiliac-femoral thromboendarterectomy and the other with aortoiliac thromboendarterectomy).

There was no statistically significant association of late patency with gender, presence of diabetes, age, or femoropopliteal-associated disease.

A statistically significant difference was observed when endarterectomy length was analyzed: $91.9 \% \pm$ $5.5 \%$ of aortoiliac-femoral thromboendarterectomies were patent after 5 years compared to $73.9 \% \pm 13.8 \%$ of others (Fig. 4).

There was a statistically significant association of the patency rate with the type of symptom (intermittent claudication or critical limb ischemia). A 5-year patency of $95.0 \% \pm 4.8 \%$ was observed for patients with intermittent claudication, while patients with critical limb ischemia had a $73.7 \% \pm$ $12.4 \%$ patency rate (Fig. 5).

Six patients died during follow up. Causes of death were acute myocardial infarction (3), ischemic cerebrovascular accident (1), leukemia (1), and intestinal perforation during gynecologic surgery (1). The life table shows the 5-year survival rate of $85.3 \% \pm 5.8 \%$ (Fig. 6).

There was no statistically significant difference in the incidence of mortality when patients were grouped according to gender, endarterectomy length, or symptom type (intermittent claudication or critical ischemia).

Statistically significant differences in the 5-year survival rates were observed when patients were grouped according to presence of diabetes $(71.5 \% \pm 14.1 \%$ versus $88.2 \% \pm 6.3 \%$ for non-diabetic patients), age $(77.7 \% \pm 11.3 \%$ for $>65$ years old versus $87.9 \% \pm 6.2 \%$ for $<65$ years old), and femoropopliteal-associated disease $(78.2 \% \pm 7.9 \%$ versus $93.3 \% \pm 6.4 \%$ for patients without femoropopliteal occlusions) (Figs. 7,8,9). 


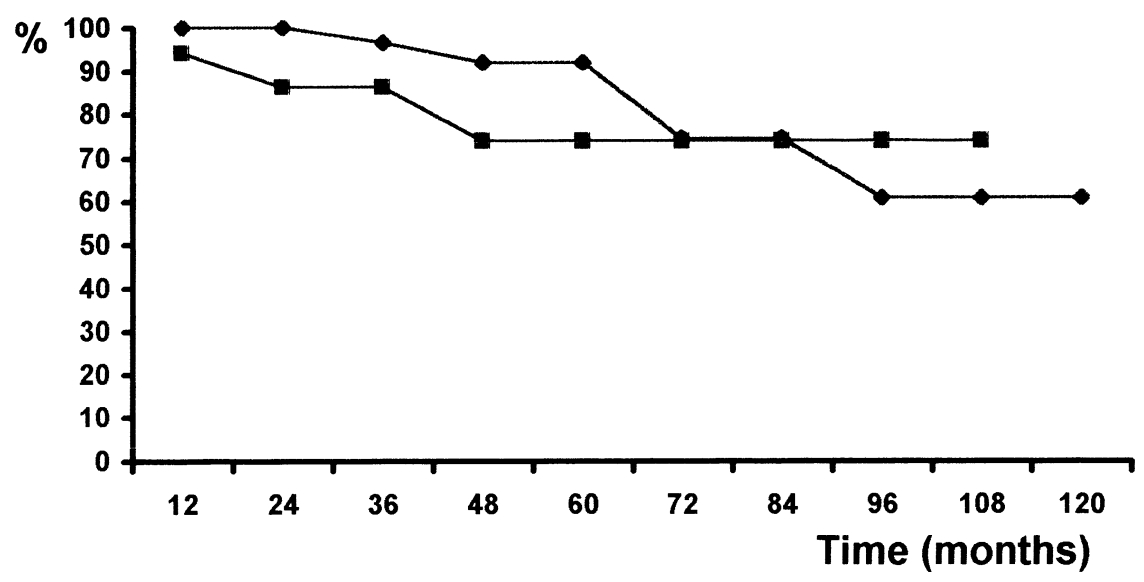

Number of operations included in the peiod:

Aorto-femoral:

$\begin{array}{lllllllllll}52 & 39 & 32 & 25 & 16 & 11 & 8 & 6 & 4 & 2 & 1\end{array}$

Other:

$\begin{array}{lllllllll}19 & 14 & 9 & 7 & 6 & 4 & 4 & 2 & 2\end{array}$

Number of occlusions:

Aorto-femoral:

$\begin{array}{cccccccccr}0 & 0 & 1 & 1 & 0 & 2 & 0 & 1 & 0 & 0 \\ \text { Other: } & 1 & 0 & 1 & 0 & 0 & 0 & 0 & 0\end{array}$

$\mathrm{p}$ Wicoxon $($ Gehan $)=0.07$

Figure 4 - Patency by length of thromboendarterectomy.

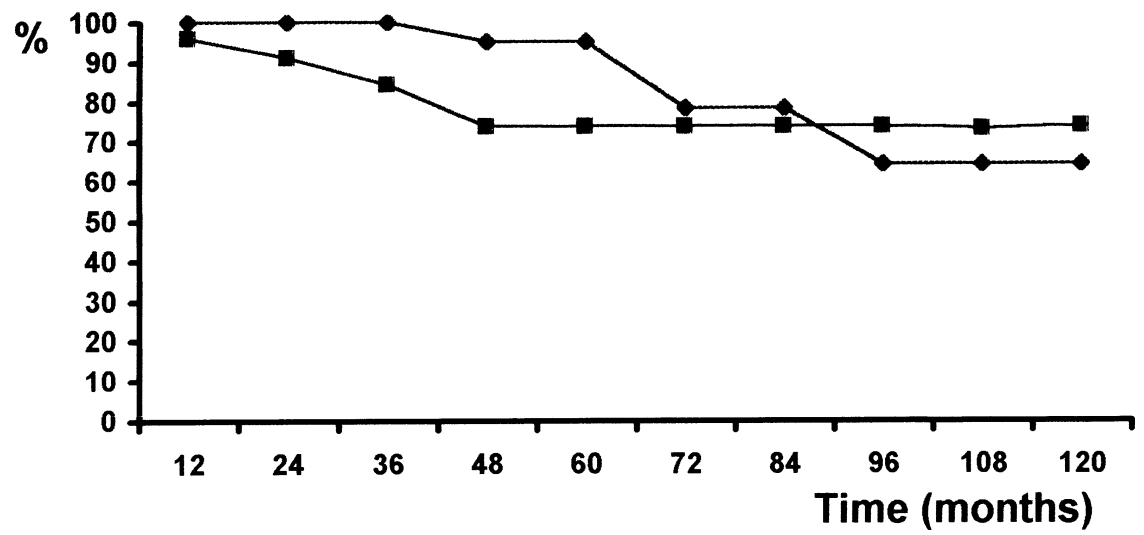

Number of operations included in the peiod:

Claudication:

$\begin{array}{lllllllllll}42 & 32 & 25 & 22 & 17 & 12 & 9 & 6 & 4 & 1 & 1\end{array}$

Critical ischemia:

$\begin{array}{llllllllll}29 & 21 & 16 & 10 & 5 & 3 & 3 & 2 & 2 & 1\end{array}$

Number of occlusions:

Claudication:

$\begin{array}{crrrrrrrr}0 & 0 & 0 & 1 & 0 & 2 & 0 & 1 & 0\end{array}$

Critical ischemia:

ロ 111

(1)

0

$\begin{array}{llll}0 & 0 & 0 & 0\end{array}$

$\mathrm{p}$ Wicoxon $($ Gehan $)=0.06$

Figure 5 - Patency of thromboendarterectomy by symptoms. 


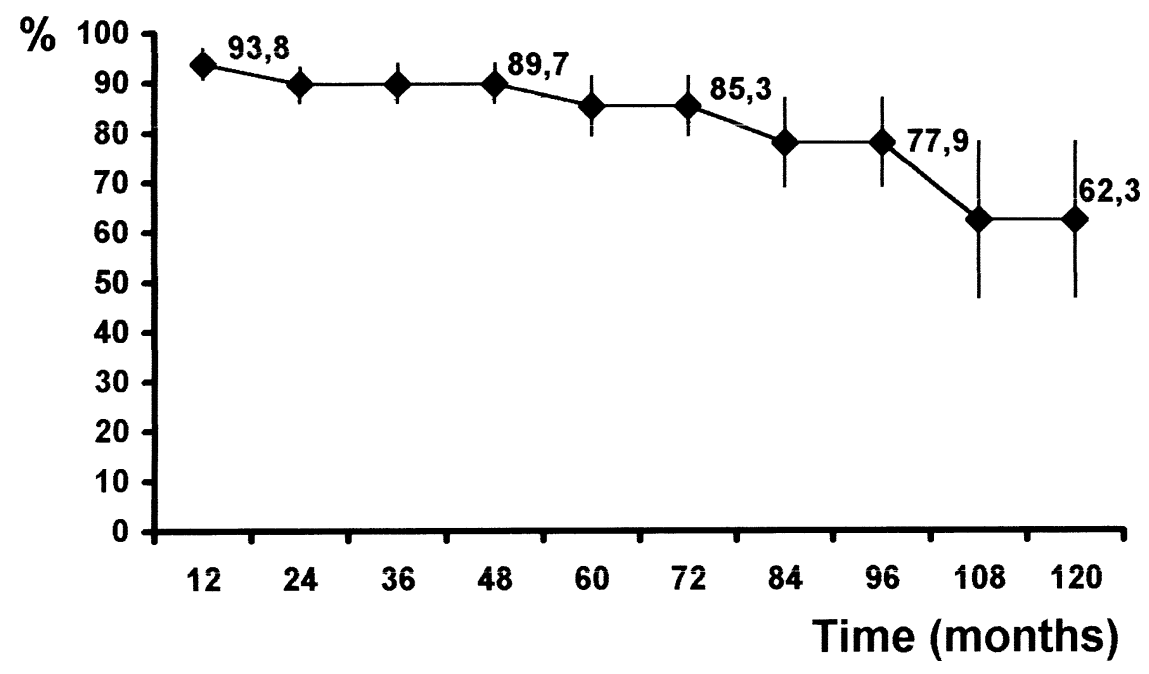

Number of patients included in the peiod:

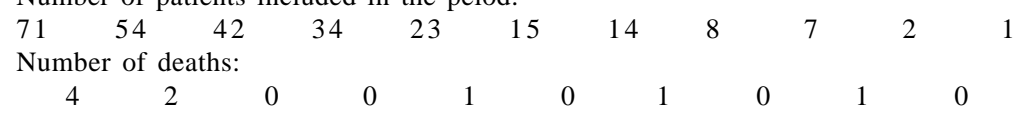

Figure 6 - Survival of the surgically treated population.

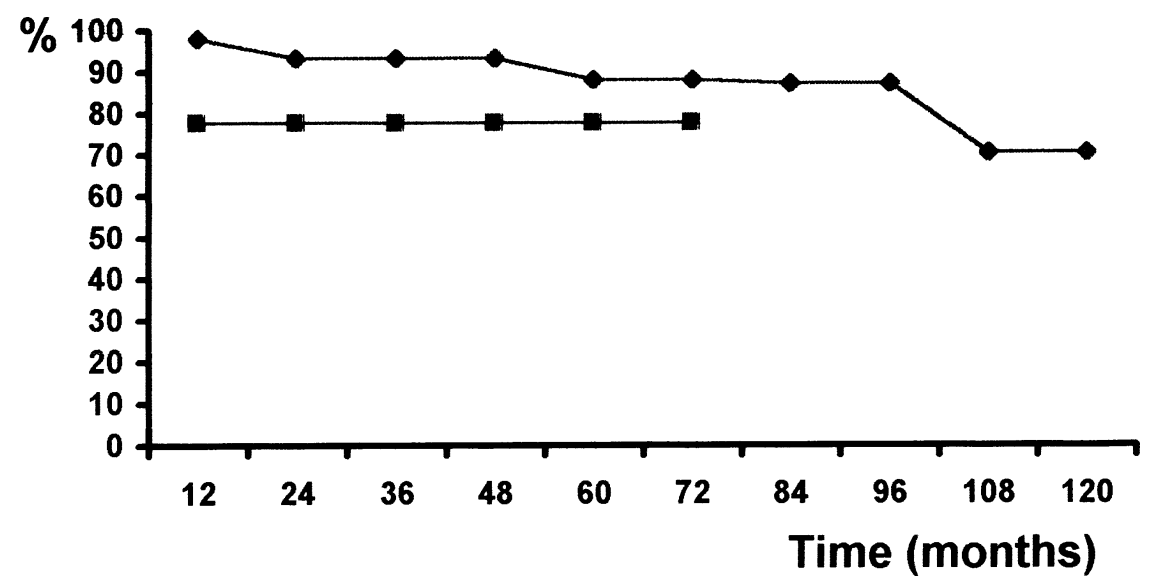

Número de doentes no período:

$<65$ anos:

$\begin{array}{lllllllllll}-56 & 45 & 35 & 29 & 20 & 14 & 13 & 8 & 7 & 2\end{array}$

$>65$ anos:

Número de eventos:

$<65$ anos:

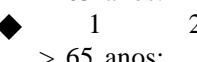

3 anos.

$\begin{array}{lllll}7 & 29 & 20 & 14 & 13 \\ 7 & 5 & 3 & 1 & 1\end{array}$




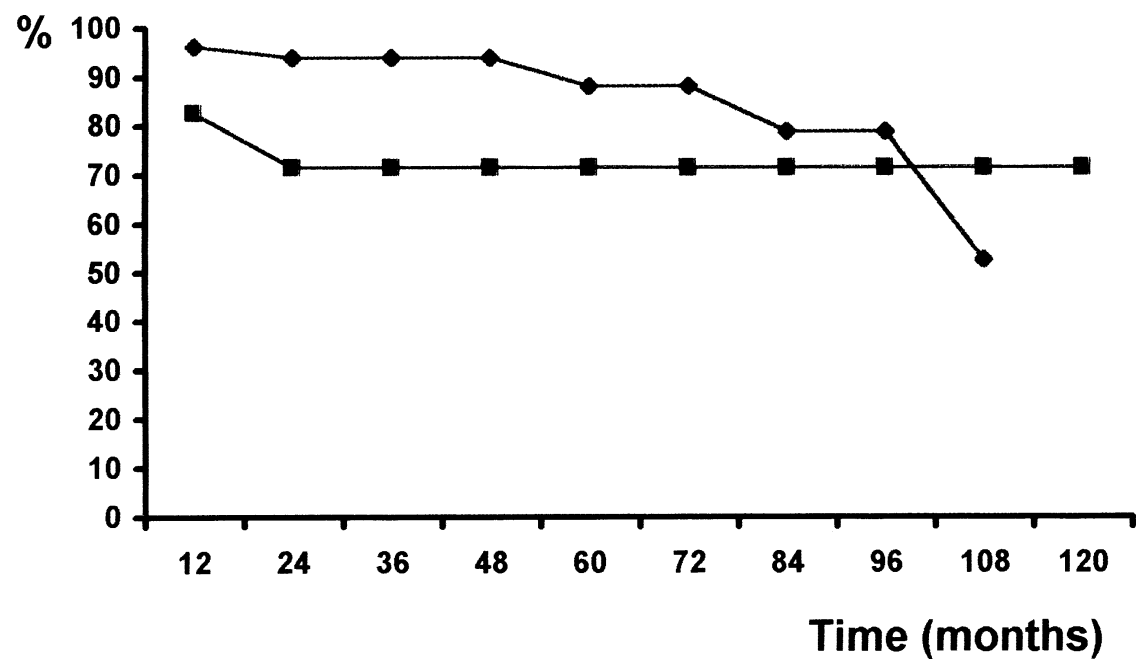

Number of patients included in the peiod:

Non-diabetic:

$\begin{array}{llllllllll}59 \quad 45 & 67 & 29 & 20 & 12 & 12 & 6 & 5 & & \\ \text { Diabetic: } & & & & & & & & & \\ 12 \quad 9 & 5 & 5 & 3 & 3 & 2 & 2 & 2 & 2 & 1\end{array}$

Number of deaths:

Non-diabetic:

2
Diabetic:

a 2

2

p Wicoxon $($ Gehan $)=0.03$

Figure 8 - Survival of the surgically treated population by diabetes mellitus.

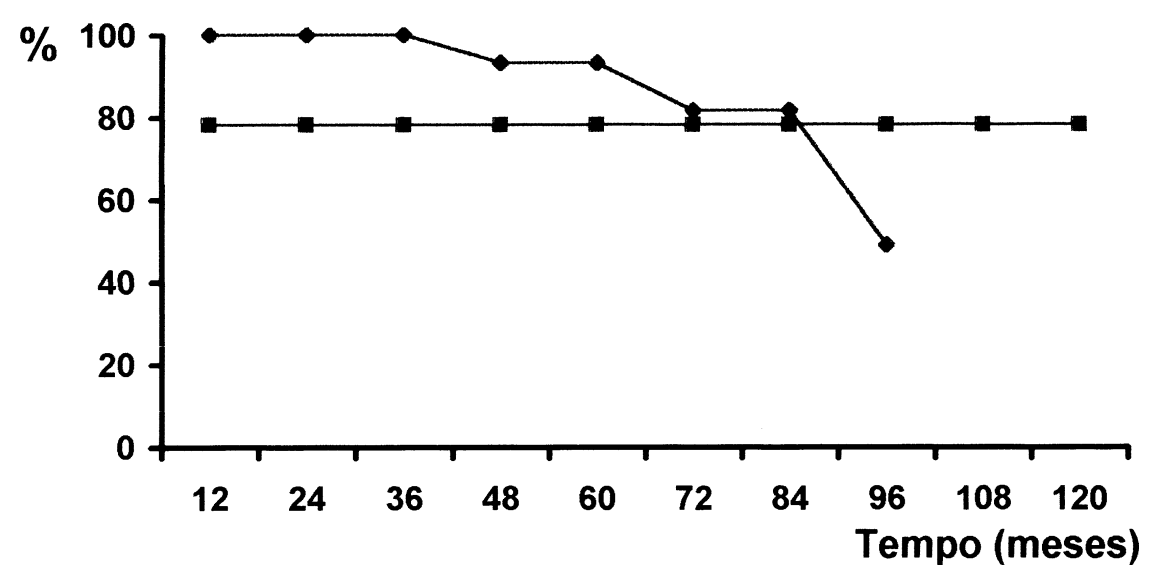

Number of patients included in the peiod:

Femoro-popliteal disease absent:

$\begin{array}{lllllllll}39 & 31 & 25 & 22 & 18 & 11 & 10 & 5 & 4\end{array}$

Femoro-popliteal disease present:

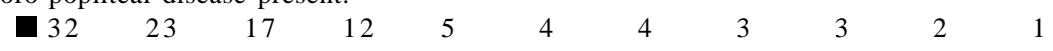

Number of deaths:

Femoro-popliteal disease absent:

$\begin{array}{ccc}0 & 0 & 0\end{array}$

$$
\begin{aligned}
& \text { ロ } \begin{array}{ccc}
4 & 2 & 0
\end{array} \\
& 0 \\
& \begin{array}{llllll}
0 & 0 & 0 & 0 & 0 & 0
\end{array} \\
& \text { p Wicoxon }(\text { Gehan })=0.08
\end{aligned}
$$

Figure 9 - Survival of the surgically treated population by femoropopliteal associated to aortoiliac-femoral disease. 


\section{DISCUSSION}

This study was initially designed to prove that endarterectomy is feasible for all atherosclerotic aortoiliacfemoral obstructions. Therefore, it is a prospective study that respects all inclusion and exclusion criteria. There are a few prospective studies in the literature $^{12-15}$. All patients complaining of Leriche's syndrome who were admitted under the author's care were prepared for ring-stripper thromboendarterectomy; patient selection exclusively on arteriography was not done. Of the 80 patients included, there were 9 excluded because of diagnosis of intraoperative aneurysm and the finding of a common iliac artery stent during surgery. The stent was not visualized on arteriography because of technicalities of the digital subtraction techniques. One important fact became very clear: thromboendarterectomy was not feasible in $10 \%$ of patients with Leriche's syndrome. Some authors had mentioned this fact before and attributed this to technical difficulties such as calcified atheroma plaques and not to aneurysms or previous procedures $^{16-18}$.

Our study population of $71 \mathrm{pa}-$ tients is smaller than other study populations reported in the literature, but it is similar in age, gender distribution, associated risk factors, cardiopathy, and distal occlusive disease. These similarities allow comparative studies of our results and those in the literature ${ }^{14,17,19-21}$.

The surgical technique employed deserves special attention. A transperitoneal access was used because we had significant previous experience with this approach. However, retroperitoneal access to the abdominal aorta has recently become accepted in our department and is now routinely employed; this was not the case at the beginning of this study ${ }^{22,23}$.

Wylie's (1952) ring endarterec- tomy technique was employed. ${ }^{3}$ Distalto-proximal artery endarterectomy diminishes aortic cross-clamping time, and a transverse arteriotomy at the arterial bifurcation makes it easier to suture, resulting in lower stenosis rates and no need for patches. Longitudinal arteriotomies frequently need patching $^{14,17,19,20}$.

At hospital dismissal time, all thromboendarterectomies were patent, even if reoperation was needed. The immediate reoperation rate was high. According to Gaspard et al. (1972) there are 4 factors that should be considered before starting an endarterectomy: 1) artery diameter (the smaller the arterial lumen the more difficult it is), 2) kinking of the artery, 3) calcifications, and 4) "almost normal" arteries, which are more difficult to endarterectomize (especially when the common femoral and common iliac arteries are compromised and external iliac artery is spared $)^{10}$. Recent data shows a reoperation rate of $1.2 \%$ even in more extensive thromboendarterectomy ${ }^{14,19,24,25}$. As already described, as surgeons become more experienced, mortality and reoperation rate diminishes ${ }^{26}$.

These are reasons why most surgeons opt for endarterectomy only when lesions are limited to aorta and common iliac arteries ${ }^{27-33}$. According to Brewster and Darling (1978), limited obstruction occurs in $10 \%$ of patients with aortoiliac occlusion, and these are the cases in which endarterectomy should be indicated because it is an autogenous repair, a great advantage over a prosthetic graft ${ }^{34}$.

According to results presented here, there is no influence of the studied variables on the reoperation rate. Technical difficulties such as cores left within the arteries or flaps left at the origin of the superficial femoral artery occurred at the beginning of the study.

There were 3 immediate amputations despite patent restorations. In the literature, there are citations of cases in which amputations were necessary after endarterectomy or aortofemoral bypass surgery for intermittent claudication, and all amputations were due to postoperative occlusion of the restored arterial segment (graft or endarterectomy $)^{35-37}$.

However, amputation does not necessarily occur only after occlusion of the arterial repair. Gaspard et al. (1972) reports 3 diabetic patients that evolved to amputation with normal postoperative femoral pulse ${ }^{12}$. Barret et al. (1985) observed the same in 2 of 424 aortofemoral restorations ${ }^{38}$.

Most postoperative amputation occurs in patients with critical ischemia ${ }^{30,39,40}$. Immediate postoperative amputation rate is low, varying from zero to $6.3 \%$ after surgery on aortoiliacfemoral territory obstruction ${ }^{20,28,30,35,39}$. This study's amputation rate falls into the accepted range. None of the amputations were due to endarterectomy failure. Two patients underwent amputation: one due to progression of gangrene and the other due to infection. The third amputation case was a transmetatarsal amputation on the contralateral side due to atheroembolism. This last case illustrates a major complication of this technique. This study reveals a high amputation risk for patients complaining of critical ischemia.

The mortality rate was $4.2 \%$ in this study. The mortality rate cited in the literature varies from $1.1 \%$ to $6.9 \%^{13,14,19,25,36}$. It is very important to emphasize that this statistic is related only to ring-stripper endarterectomy, since the usual technique employed to treat aortoiliac-femoral occlusions is synthetic bypass. The reported mortality rate following aortobifemoral bypass surgery ranges from $2 \%$ to $5 \%$ 28, 33,37,41-43.

Initially, there were technical difficulties that included determination of the ideal surgical access and endarterectomy extension. Older studies report the same technical difficulties and also 
report a decrease in complication and mortality rates as the surgeon's experience increases ${ }^{20,44,45}$. Immediate death analysis reveals that all 3 patients had associated femoropopliteal occlusion, and 2 were diabetic. All 3 had an aortoiliac-femoral thromboendarterectomy. Statistical analysis revealed a significant difference when diabetes and femoropopliteal occlusions were analyzed. This means that when present, these variables increase immediate postoperative mortality risk. According to Brewster (1991), multisegment disease usually occurs in older patients-mostly males, who are diabetics with coronary and cerebral and visceral artery involvement/occlusions $^{27}$. Other authors report an increase in mortality associated with age, female gender, femoropopliteal disease - especially when there is critical ischemia — and associated with the extent of the endarterectomy ${ }^{14,28}$.

Mesenteric thrombosis was the cause of death of a diabetic patient with associated femoropopliteal occlusion. Deaths in the other cases were associated with technical difficulties during aortoiliac-femoral thromboendarterectomy. These data support an extensive preoperative patient evaluation, especially if diabetes and distal artery occlusions are present. No early postoperative deaths occurred in the aortoiliac and iliofemoral thromboendarterectomy group. Similar results have been reported by other surgeons ${ }^{35}$.

Late patency is an important factor to be analyzed in arterial repair. Five years after initial thromboendarterectomy, the patency rate was $87.3 \% \pm 6.9 \%$ (late reoperations are not included). All 6 cases of late occlusions could be treated -4 by thromboendarterectomy and 2 by Dacron bypass. Causes of occlusion were intimal hyperplasia and progression of atherosclerotic disease distal to prior thromboendarterectomy. Intimal hyperplasia is a very important issue still under study, especially in angioplasties, and cannot be avoided ${ }^{46-50}$ Published data shows a 5-year patency rate of $64.9 \%$ to $91 \%$ for aortofemoral repair $^{9,24,28,33,37,38,51,52}$. Factors such as age, gender, diabetes, type of repair (thromboendarterectomy or bypass) did not influence these results, but patient complaint was very important. In our study, $91.3 \% \pm 8.3 \%$ of thromboendarterectomies associated with intermittent claudication were patent after 5 years versus only $81.3 \%$ $\pm 10.2 \%$ of thromboendarterectomies associated with critical ischemia. These results were statistically significant and agree with those of other reported studies $^{14,27,28,43}$. These excellent results support the use of surgical intervention in patients with intermittent claudication and good clinical status on preoperative evaluations ${ }^{35,52,53}$.

Another important result is that longer thromboendarterectomies have longer patency times than shorter ones do. Darling and Linton (1964) and Wylie (1976) have already called attention to the fact that thromboendarterectomy should be "complete"; that is, all plaques should be removed, and if necessary, thromboendarterectomy should be extended to the first branch of the deep femoral artery. This theory supports the criteria used in our service to always employ aortofemoral bypass for aortoiliac occlusions, since small lesions not bypassed may compromise the arterial repair afterwards ${ }^{19,45,54}$. Reports in the literature support that patients with limited lesions, especially aortoiliac, evolve with good results on late evaluations ${ }^{26,38,44,45}$. But the present article is highly suggestive that late occlusions develop from smaller atheroma plaques on distal arteries that were not considered during aortoiliac or iliac-femoral thromboendarterectomy.

The survival rate of our study population shows that $87.5 \% \pm 4.5 \%$ of pa- tients were still alive after 5 years. A similar study for aortofemoral bypass performed in our service had a $75.6 \%$ survival rate after 5 years ${ }^{4}$. Neugebauer and Heyn (1982) estimated that $78 \%$ of patients who underwent surgery for aortoiliac occlusions were alive after 5 years $^{55}$. Szilagyi et al. (1986) estimated that only $59 \%$ of patients were alive after 5 years (same diagnoses and treatment) ${ }^{33}$. The cause of death was primarily cardiovascular, especially acute myocardial infarction $^{16,26,28,29,33,37,38,42,56}$.

There were no deaths related to late complications of thromboendarterectomy, in contrast to what occurs with aortofemoral prosthetic bypass. Previous studies done in this hospital have demonstrated that a high risk of developing infection and anastomotic aneurysm exists when Dacron prostheses are used, and that use of these devices is associated with some deaths; the second most frequent cause of late death is complications related to the use of prosthetic graft ${ }^{6,7,9,57,58}$. The same results are reported from different vascular centers ${ }^{59-64}$. Raptis et al. (1995) report a $1 \%$ per year postsurgical complication rate associated with aortofemoral bypass for up to 10 years after surgery ${ }^{65}$. The 5-year survival rate of this study is higher than previous survival rates of the population we treated with aortofemoral bypass. It is also higher than survival rate of most authors except for Barret et al. (1985) who report an 89\%, 5-year survival rate for patients with aortofemoral Dacron bypass ${ }^{12}$. The small number of patients studied here and the better cardiologic follow-up today than before certainly influenced this result. Nevertheless, uncertainty persists regarding whether late complications and reoperations associated with using a prosthetic graft can be avoided, which would result in diminished late mortality ${ }^{9}$.

When the survival rate is analyzed according to gender, kind of operation, 
and patient complaint, no significant statistical differences emerged. Some authors report that women may not evolve as well as men, especially younger women in the premenopausal period $^{66}$. This observation becomes more evident with repairs below the inguinal ligament, but is not that evident when the aorta is involved ${ }^{67,68}$. Crawford et al. (1981) reports a 949 patient series whose survival rate is lower when critical ischemia, older age, and diabetes are present ${ }^{28}$. The statistically significant differences found in this study suggest that older age, presence of diabetes, and associated femoropopliteal occlusion are all factors contributing to a lower 5-year survival rate.

In conclusion, thromboendarterectomy is feasible for $90 \%$ of aortoiliacfemoral occlusions and should be kept in the surgical arsenal, since it is autogenous and has no extension limits. In the past few years, angioplasty has increased its popularity, but it still is not feasible for more extensive lesions, and stents are often needed, resulting in the higher rates of complications that are associated with the use of Dacron prosthetic grafts ${ }^{44,69,70}$.

We conclude that thromboendarterectomy is an adequate technique to treat $90 \%$ of aortoiliac-femoral atherosclerotic occlusions, early mortality rate is similar to that of other aortoiliac repairs, mortality is higher in patients who have diabetes mellitus and femoropopliteal-associated occlusion, early amputation rate is low and frequently associated with critical ischemia, there is a high reoperation rate, most late deaths are due to cardiovascular causes, and it is a durable restoration.
AGUIAR ET e col. - Trombendarterectomia aorto-femoral. Rev. Hosp. Clín. Fac. Med. S. Paulo 57(4): 147-160, 2002.

OBJETIVO: Estudar a exeqüibilidade da trombendarterectomia em todos os portadores de obstrução aortilíaco-femoral aterosclerótica, seus resultados imediatos e tardios.

MÉTODO: Trabalho clínico, prospectivo e descritivo feito em hospital universitário. Os critérios de inclusão foram: obstrução aortilíaco-femoral aterosclerótica associada ou não a obstruções fêmoro-poplíteas, condições clínicas para suportar cirurgia de gran- de porte e ausência de restaurações arteriais nos territórios aortofemoral e fêmoro-poplíteo. Os critérios de exclusão foram: aneurismas, doença arterial inflamatória e restauração arterial prévia reconhecidos apenas no ato cirúrgico. Foram incluídos 80 doentes. Nove $(11,2 \%)$ foram excluídos. Participaram do estudo 71 doentes, 54 homens $(76,1 \%)$ e 17 mulheres $(23,9 \%)$, com média de idades igual a 57,3 $\pm 9,9$ anos. As indicações cirúrgicas foram claudicação intermitente e isquemia crítica. A técnica da trombendarterectomia com anéis foi empregada em todos doentes. Os resultados foram relacionados: a idade, sexo, queixa, di- abetes mellitus, extensão da trombendarterectomia, extensão da doença obstrutiva arterial. Para a análise estatística foram empregados os testes de Qui quadrado ou exato de Fisher quando necessários e Wilkoxon (Gehan) para comparação de curvas de sobrevivência.

RESULTADOS: Sessenta e oito (100\%) restaurações estavam pérvias. A obstrução imediata ocorreu em 13 $(18,3 \%)$ doentes e 12 foram reoperados com sucesso. Não houve diferenças significativas na distribuição das reoperações em relação às variáveis estudadas. Houve três amputações (4,2\%) no grupo de isquemia crítica. A mor- 
talidade foi $4,2 \%$ e aumentou significativamente nos pacientes diabéticos e nos que apresentaram obstruções fêmoro-poplíteas associadas. Após cinco anos $87,0 \pm 5,6 \%$ das restaurações estavam pérvias; isquemia crítica e endarterectomias aorto-ilíacas ou ilíaco-femorais estavam associadas à durabilidade menor. Após cinco anos $85,3 \pm 5,8 \%$ dos doentes estavam vi- vos; diabetes, idade acima de 65 anos e obstruções fêmoro-poplíteas associadas estavam relacionadas à diminuição da sobrevida dos pacientes.

CONCLUSÕES: A trombendarterectomia pode ser aplicada em aproximadamente $90 \%$ dos casos de obstruções ateroscleróticas aortilíacofemorais, a mortalidade imediata é aceitável, a taxa de amputações maiores imediatas é baixa, a taxa de reoperações imediatas é mais alta, os óbitos tardios são de causa cárdio-vascular na sua maioria, a restauração é durável principalmente quando indicada para tratamento da claudicação intermitente.

DESCRITORES: Aorta. Artéria ilíaca. Endarterectomia. Aterosclerose. Restauração arterial.

\section{REFERENCES}

1. DOS SANTOS JC - Sur la désobstruction des thromboses artérielle anciennes. Mem Acad Chir. 1947; 73:409-12.

2. BAZY L \& REBOUL H - Technique del'endartériectomie desoblitérante. J Int Chir 1950; 65:196-8.

3. WYLIE EJ - Thromboendarterectomy for arteriosclerotic thrombosis of major arteries. Surgery 1952; 23:275-9.

4. BLAKEMORE AHP \& VOORHEES AB - The use of tubes constructed from vinyon " $\mathrm{N}$ " cloth in bridging arterial defects - Experimental and clinical. Ann Surg 1954; 140:324-34.

5. AGUIAR ET, ALBERS MTV, LANGER B et al. - Incidência de infecções comprometendo próteses arteriais. Rev Paul Med 1985; 103:239-42.

6. AGUIAR ET, ALBERS MTV, LANGER B et al. - Reoperação para correção de aneurismas anastomóticos femorais sequentes a derivações aorto-femorais. Rev Assoc Med Bras 1977; 23:20910 .

7. AGUIAR ET, ALBERS MTV, LANGER, B et al. -Tratamento cirúrgico de infecções comprometendo próteses arteriais em posição aorto-femoral. Rev Hosp Clin Fac Med S Paulo 1993; 48:76-81.

8. AGUIAR ET, LANGER B \& LOBATO, A.C. - Le risque de survenue de faux anévrysme et d'infection prothétique après pontage prothétique aorto-fémoral. Étude retrospective. A propos de 211 cas. J Mal Vasc 1996; 21:36-9.

9. ALBERS M, MANASTERSKI J, AGUIAR ET et al. - Resultados tardios e complicações específicas das derivações aortofemorais. Cir Vasc Angiol 1996; 11:86-91.

10.PUECH-LEÃO LE, BOUABCI AS, WOLOSKER, M et al. - A durabilidade da restauração vascular nas oclusões crônicas aortoilíacas. Rev AMB 1971; 17:407-12.
11.PUECH-LEÃO LE, WOLOSKER M, CINELLI JR. M et al. Considerações cirúrgicas sobre 126 casos de oclusão crônica aorto-ilíaca. Rev Paul Med 1967; 70:275-87.

12.GASPARD DJ, COHEN JL \& GASPAR MR- Aortoiliofemoral thromboendarterectomy vs bypass graft. A randomized study. Arch Surg 1972; 105:898-901.

13.NASH T - Aortoiliac occlusive vascular disease: a prospective study of patients treated by endarterectomy and bypass procedures. Aust NZJ Surg 1979; 49:223-7.

14.OERTLI D, WIGGER J, LANDMANN J et al. - Long-term results after semiclosed thrombendarterectomy for aortoiliac occlusive disease. Eur J Vasc Endovasc Surg 1996; 11:432-6.

15.PASSMAN MA, TAYLOR LM, MONETA GL et al. - Comparison of axillofemoral and aortofemoral bypass for aortoiliac occlusive disease. J Vasc Surg 1996; 23:263-71.

16.BLONDEAU PH \& SAUTOT J - Les résultats éloignés de la chirurgie artérielle restauratrice de l'aorte sous-rénale. J Chir (Paris) 1967; 94:183-242.

17.IMPARATO A.M, SANOUDOS G, EPSTEIN HY et al. - Results in 96 aortoiliac reconstructive procedures: Preoperative angiographic and functional classifications used as prognostic guides. Surgery 1970; 68:610-6.

18.AGRIFOLIO G, AGUS GB \& CASTELLI P - La tromboendoarterectomia del segmento aortoiliaco-femorale. Min Med 1979; 70:2193-7.

19.DARLING RC \& LINTON RR - Aortoiliofemoral endarterectomy for atherosclerotic occlusive disease. Surgery 1964; 55:18494.

20.NAYLOR AR, AH-SEE AK \& ENGESET J - Aortoiliac endarterectomy: an 11-year review. Br J Surg 1990; 77:190-3. 
21.WAIBEL PP \& DUNANT JH - Late results of aorto-iliac reconstructive surgery. J Cardiovasc Surg 1973; 14:492-4.

22.PECK JJ, McREYNOLDS DG, BAKER DH et al. - Extraperitoneal approach for aortoiliac reconstruction of the abdominal aorta. Amer J Surg 1986; 151:620-3.23. REILLY JM - Retroperitoneal aortoiliac reconstruction. Surg Clin N Amer 1995; 75:679-90.

24.OSKAM J, VAN DEN DUNGEN JJAM \& BOONTJE AH Thromboendarterectomy for occlusive disease of the common iliac artery. Cardiovasc Surg 1996; 4:356-9.

25.PERDUE GD, LONG WD \& SMITH RB - Perspective concerning aorto-femoral arterial reconstruction. Ann Surg 1971; 173:940-

26.DEAN RH \& FOSTER JH - Aortoiliac occlusive disease: fifteen years' operative experience. Southern Med J 1973; 66:813-7.

27.BREWSTER DC - Clinical and anatomical considerations for surgery in aortoiliac disease and results of surgical treatment. Circulation 1991; 839(suppl.I):42-52.

28.CRAWFORD ES, BOMBERGER RA, GLAESER DH et al. Aortoiliac occlusive disease: Factors influencing survival and function following reconstructive operation over a twentyfive-year period. Surgery 1981; 90:1055-67.

29.KUSABA A, INOKUCHI K, KAMORI M et al. - Long-term results of reconstructive surgery for aorto-iliac arterial occlusive lesions. Jpn J Surg 1980; 10:238-44.

30.PILCHER DB, BARKER WF \& CANNON JA - An aortoiliac endarterectomy case series followed 10 years or more. Surgery $1970 ; 67: 5-17$.

31.PUECH-LEÃO LE, BOUABCI AS \& TOLEDO OM - Complicações pós-operatórias da cirurgia vascular. Rev AMB 1964; 10:299304.

32.PUECH-LEÃO LE, BOUABCI AS, WOLOSKER M et al. - A durabilidade da restauração vascular nas oclusões crônicas aortoilíacas. Rev AMB 1971; 17:407-12.

33.SZILAGYI DE, ELLIOTT JP, SMITH RF et al. - A thirty-year survey of the reconstructive surgical treatment of aortoiliac occlusive disease. J Vasc Surg 1986; 3:421-36.

34.BREWSTER DC \& DARLING RC - Optimal methods of aortoiliac reconstruction. Surgery $1978 ; \mathbf{8 4}: 739-48$

35.KING RB, MYERS KA, SCOTT DF et al. - Aortoiliac reconstructions for intermittent claudication. Br J Surg 1982; 69:169-72.

36.KOUCHOUKOS NT, LEVY JF, BALFOUR JF et al. - Operative therapy for aortoiliac arterial occlusive disease. A comparison of therapeutic methods. Arch Surg 1968; 96:628-35.

37.NEVELSTEEN A, SUY R, DAENEN W et al. - Aortofemoral grafting: factors influencing late results. Surgery 1980; 88:64253.

38.BARRET A, PRADÈRE B, COSTECALDE M et al. - Réflexions a propos de 180 pontages aorto-bifémoraux pour artérite chronique oblitérante. J Mal Vasc 1985; 10:141-6.

39.GALLAND RB, HILL DA, GUSTAVE R et al. - The functional results of aorto-iliac reconstruction. Brit J Surg 1980; 67:3446.
40.GOLDSTEIN M, FLAMAND JP, BELENGER J et al. - Early and late results of aortic and iliac reconstructive operations. J Cardiovasc Surg (Torino) 1972; 13:454-8.

41.MALONE JM, MOORE WS \& GOLDSTONE J - The natural history of aorto-bilateral femoral bypass grafts for lower extremity ischemia. J Cardiovasc Surg 1976; 17:83.

42.BREWSTER DC - Current controversies in the management of aortoiliac occlusive disease. J Vasc Surg 1997; 25:365-79.

43.FIORANI P, SPARTERA C \& PISTOLESE GR - Indicazioni al trattamento chirurgico delle lesioni aortoiliache: il bypass aortofemorale. Min Med 1979; 70:2189-92.

44.SEDWITZ MM, HYE RJ, FREISCHLAG JA et al. - Zero operative mortality rate in 109 consecutive elective aortic operations performed by residents. Surg Gynec Obstet 1990; 170:385-9.

45.WYLIE E.J, OLCOTT IV C \& STRING ST - Aortoiliac thromboendarterectomy. In: Varco RL \& Delaney JP Controversy in Surgery. Philadelphia, Saunders, 1976. p.43750

46.ERDOES LS, BERNHARD VM \& BERMAN SS - Aortofemoral graft occlusion: strategy and timing of operation. Cardiovasc Surg 1995; 3:227-83

47.HAIART DC, CALLAM MJ, MURIE JÁ et al. - Reoperations for late complications following abdominal aortic operation. Br J Surg 1991; 78:204-6.

48.NIKKARI ST \& CLOWES AW - Restenosis after vascular reconstruction. Ann Med 1994; 26:95-100.

49.TAPPER SS, EDWARDS WH, EDWARDS JR. WH et al. - Recurrent aortic occlusion. Am Surg 1994; 60:148-50.

50. TINGAUD R, SERISE JM, LE HERON D et al. - Late reoperations after aorto-iliac restaurations. J Cardiovasc Surg 1980; 21:665-8.

51.ALLEN BT, RUBIN BG, REILLY JM et al. - Limb salvage and patency after aortic reconstruction in younger patients. Amer J Surg 1995, 170:188-92.

52.SLADEN JG, GILMOUR JL \& WONG RW - Cumulative patency and actual palliation in patients with claudication after aortofemoral bypass. Amer J Surg 1986; 152:190-5.

53.REGENSTEINER JG, HARGARTEN ME, RUTHERFORD RB et al. - Functional benefits of peripheral vascular bypass surgery for patients with intermittent claudication. Angiology 1993; 44:1-10.

54.PUECH-LEÃO LE, WOLOSKER M, CINELLI JR. M et al. Considerações cirúrgicas sobre 126 casos de oclusão crônica aorto-ilíaca. Rev Paul Med 1967; 70:275-87.

55.NEUGEBAUER J \& HEYN G - Survival rates after reconstructions in the aorto-iliac region. J Cardiovasc Surg 1982; 23:229-30.

56.LORENZI G, DOMANIN M, COSTANTINI A et al. - Role of bypass, endarterectomy, extra-anatomic bypass and endovascular surgery in unilateral iliac occlusive disease: a review of 1257 cases. Cardiovasc Surg 1994; 2:370-3.

57.AGUIAR ET, VOLKOFF AC, SANTOS JL et al. - Sobrevivência após derivações arteriais com próteses de Dacron. Rev Hosp Clin Fac Med S Paulo 1993; 48:220-3. 
58.AGUIAR ET, LANGER B, ALBERS MTV et al. - Infecção compromentendo próteses arteriais: quadro clínico, etiologia e fatores predisponentes. Rev Hosp Clin Fac Med S Paulo 1993; 48:8-12.

59.BERGQVIST D, BJÖRKMAN H, BOLIN T et al. - Secondary aorto-enteric fistulae - Changes from 1973 to 1993. Eur J Vasc Endovasc Surg 1996; 11:425-8.

60.CHOPIN D, THEBAULT S \& LAGNEAU P - Faux anévrysmes prothétiques. Évaluation des facteurs étiologiques. J Chir (Paris) 1983; 120:603-9.

61.FERNANDES RA; DI MARIA G, FOURMESTRAU X et al. Falsos-aneurismas anastomóticos aórticos em próteses aortobifemorais - importância do diagnóstico. Cir Vasc Angiol 1994; 10:87-93.

62.HAIART DC, CALLAM MJ, MURIE JÁ et al. - Reoperations for late complications following abdominal aortic operation. Br J Surg 1991; 78:204-6.

63.VAN BAALEN JM, KLUIT AB, MAAS J et al. - Diagnosis and therapy of aortic prosthetic fistulas: trends over a 30-year experience. Brit J Surg 1996; 83:1729-34.

64.VAN DEN AKKER PJ, BRAND R, VAN SCHILFGAARDE R et al - False aneurism after prosthetic reconstructions for aortoiliac obstructive disease. Ann Surg 1989; 210:658-66.
65.RAPTIS S, FARIS I, MILLER J et al. - The fate of the aortofemoral graft. Eur J Vasc Endovasc Surg 1995; 9:97-102.

66.BROOMÉ A, CHRITENSON JT, EKLÖF B et al. - Aorto-iliac disease in premenopausal women. Acta Chir Scand 1980; 146:555-7.

67.ENZIER MA, RUOSS M, SEIFERT B et al. - The influence of gender on the outcome of arterial procedures in the lower extremity. Eur J Vasc Endovasc Surg 1996; 11:446-52.

68.CRONENWETT JL, DAVIS JR. JT, GOOCH JB et al. - Aortoiliac occlusive disease in women. Surgery 1980; 88:775-84.

69.CORMIER F. - Chirurgie retauratrice aorto-iliaque. Endartérectomies. Encycl. Méd. Chir (Elsevier, Paris), Techniques chirurgicales - Chirurgie vasculaire, 43-032, 1997, 26 p.

70.MARZELLE J, CHAUFOUR X, LUYZI F et al. - Chirurgie restauratrice aorto-iliaque: revascularisations endovasculaires (II). Encycl. Méd. Chir. (Elsevier, Paris), Techniques chirurgicales - Chirurgie vasculaire, 43-038-B, 1998, 6p.

Received for publication on November 13, 2001. 